\title{
Catalytic isomerization of 2-methyl-3-butenenitrile by Nickel systems using bis-diphosphinoferrocene ligands: Evidence for hemilability.
}

\author{
Alberto Acosta-Ramirez, ${ }^{\dagger}$ Miguel Muñoz-Hernández, ${ }^{\S}$ William D. Jones ${ }^{t}$ and \\ Juventino J. García ${ }^{\dagger}$.*
}

†Facultad de Química, Universidad Nacional Autónoma de México, México City, 04510. México.

§Centro de Investigaciones Químicas, Universidad Autónoma del Estado de Morelos, Morelos, 62210. México.

†Department of Chemistry. University of Rochester, Rochester, New York, 14627, USA.

\section{INDEX}

Table S-1. Full table for GC-MS determinations.

Figure S-1. GC-MS chromatograms.

General Experimental Procedures

Preparation of complex 1

Experimental Details for Catalytic Experiments

${ }^{1} \mathrm{H}$ and ${ }^{13} \mathrm{C}\left\{{ }^{1} \mathrm{H}\right\}$ NMR spectra for complex 1 at room temperature.

\footnotetext{
† Facultad de Química, Universidad Nacional Autónoma de México.

$\S$ Centro de Investigaciones Químicas, Universidad Autónoma del Estado de Morelos.

${ }^{*}$ Department of Chemistry. University of Rochester.
} 
Table S-1. Full tables for GC-MS determinations.

Catalytic isometization of $2 \mathrm{M} 3 \mathrm{BN}$.

Conditions: neat $2 \mathrm{M} 3 \mathrm{BN}+\left[\mathrm{Ni}(\mathrm{COD})_{2}\right]+\mathrm{L}=110: 1: 1 ; \mathrm{T}=100^{\circ} \mathrm{C}$

\begin{tabular}{|c|c|c|c|c|c|c|c|c|}
\hline Entry & Ligand & $\begin{array}{l}\text { Time } \\
\text { (h) }\end{array}$ & $\begin{array}{c}\text { Conv } \\
\text { 2M3BN } \\
(\%) \\
\end{array}$ & $\begin{array}{c}Z- \\
2 M 2 B N(\% \\
) \\
\end{array}$ & $\begin{array}{c}\text { E-2M2BN } \\
(\%)\end{array}$ & $\begin{array}{c}\text { c-2PN } \\
(\%)\end{array}$ & $\begin{array}{c}\text { 3-PN } \\
(\%)\end{array}$ & $\begin{array}{l}\text { 4-PN } \\
(\%)\end{array}$ \\
\hline 1 & dppf & 2.5 & 100 & 10 & 2 & 4 & 84 & 0 \\
\hline 2 & tBuppf & 2.5 & 7 & 0 & 1 & 0 & 6 & 0 \\
\hline 3 & tBuppf & 15 & 98 & 11 & 5 & 6 & 76 & 0 \\
\hline 4 & dipf & 2.5 & 0 & - & - & - & - & - \\
\hline 5 & dipf & 120 & 39 & 13 & 17 & 1 & 8 & 0 \\
\hline 6 & dppf-N & 2.5 & 0 & - & - & - & - & - \\
\hline 7 & dppf-N & 36 & 95 & 18 & 4 & 3 & 70 & 0 \\
\hline
\end{tabular}

Catalytic isomerization of $2 \mathrm{M} 3 \mathrm{BN}$ with $\mathrm{ZnCl}_{\mathbf{2}}$ as cocatalyst.

Conditions: neat $2 \mathrm{M} 3 \mathrm{BN}+\left[\mathrm{Ni}(\mathrm{COD})_{2}\right]+\mathrm{L}+\mathrm{ZnCl}_{2}=110: 1: 1: 1 ; \mathrm{T}=100^{\circ} \mathrm{C}$

\begin{tabular}{|c|c|c|c|c|c|c|c|c|}
\hline Entry & Ligand & $\begin{array}{c}\text { Time } \\
\text { (h) }\end{array}$ & $\begin{array}{c}\text { Conv. } \\
\text { 2M3BN } \\
(\%)\end{array}$ & $\begin{array}{c}\mathrm{Z}- \\
2 \mathrm{M} 2 \mathrm{BN}(\% \\
)\end{array}$ & $\begin{array}{c}\text { E-2M2BN } \\
(\%)\end{array}$ & $\begin{array}{c}\text { c-2PN } \\
(\%)\end{array}$ & $\begin{array}{c}\text { 3-PN } \\
(\%)\end{array}$ & $\begin{array}{c}\text { 4-PN } \\
(\%)\end{array}$ \\
\hline 1 & dppf & 5 & 100 & 34 & 2 & 10 & 54 & 0 \\
\hline 2 & tBuppf & 15 & 8 & 2 & 2 & 1 & 3 & 0 \\
\hline 3 & tBuppf & 144 & 100 & 19 & 10 & 1 & 70 & 0 \\
\hline 4 & $\operatorname{dipf}$ & 15 & 18 & 8 & 11 & 0 & 0 & 0 \\
\hline 5 & $\operatorname{dipf}$ & 144 & 98 & 33 & 62 & 0 & 3 & 0 \\
\hline 6 & dppf-N & 15 & 100 & 25 & 66 & 0 & 9 & 0 \\
\hline 7 & $\begin{array}{c}\text { Complex } \\
1\end{array}$ & 144 & 100 & 19 & 10 & 0 & 71 & 0 \\
\hline
\end{tabular}

Catalytic isomerization of $2 \mathrm{M} 3 \mathrm{BN}$ with $\mathrm{BEt}_{3}$ as cocatalyst.

Conditions: neat $2 \mathrm{M} 3 \mathrm{BN}$ ind $+\left[\mathrm{Ni}(\mathrm{COD})_{2}\right]+\mathrm{L}+\mathrm{B}(\mathrm{Et})_{3}=110: 1: 1: 1 ; \mathrm{T}=100^{\circ} \mathrm{C}$.

\begin{tabular}{|c|c|c|c|c|c|c|c|c|}
\hline Entry & Ligand & time & $\begin{array}{c}\text { Conv. } \\
\text { 2M3BN } \\
(\%) \\
\end{array}$ & $\begin{array}{c}Z- \\
2 \mathrm{M} 2 \mathrm{BN}(\% \\
) \\
\end{array}$ & $\begin{array}{c}\text { E-2M2BN } \\
(\%)\end{array}$ & $\begin{array}{l}\text { c-2PN } \\
(\%)\end{array}$ & $\begin{array}{l}\text { 3-PN } \\
(\%)\end{array}$ & $\begin{array}{l}\text { 4-PN } \\
(\%)\end{array}$ \\
\hline 1 & dppf & 15 & 0 & 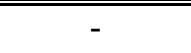 & - & - & - & - \\
\hline 2 & dppf & 120 & 10 & 0 & 3 & 0 & 7 & 0 \\
\hline 3 & tBuppf & 15 & 26 & 3 & 1 & 0 & 22 & 0 \\
\hline 4 & tBuppf & 36 & 95 & 10 & 3 & 2 & 80 & 0 \\
\hline 5 & dpif & 15 & 15 & 8 & 5 & 0 & 2 & \\
\hline 6 & $\operatorname{dipf}$ & 40 & 100 & 45 & 50 & 0 & 5 & 0 \\
\hline 7 & dppf-N & 15 & 91 & 9 & 8 & 3 & 71 & \\
\hline 8 & dppf-N & 20 & 97 & 16 & 7 & 2 & 72 & 0 \\
\hline
\end{tabular}


Figure S-1. GC-MS chromatograms.
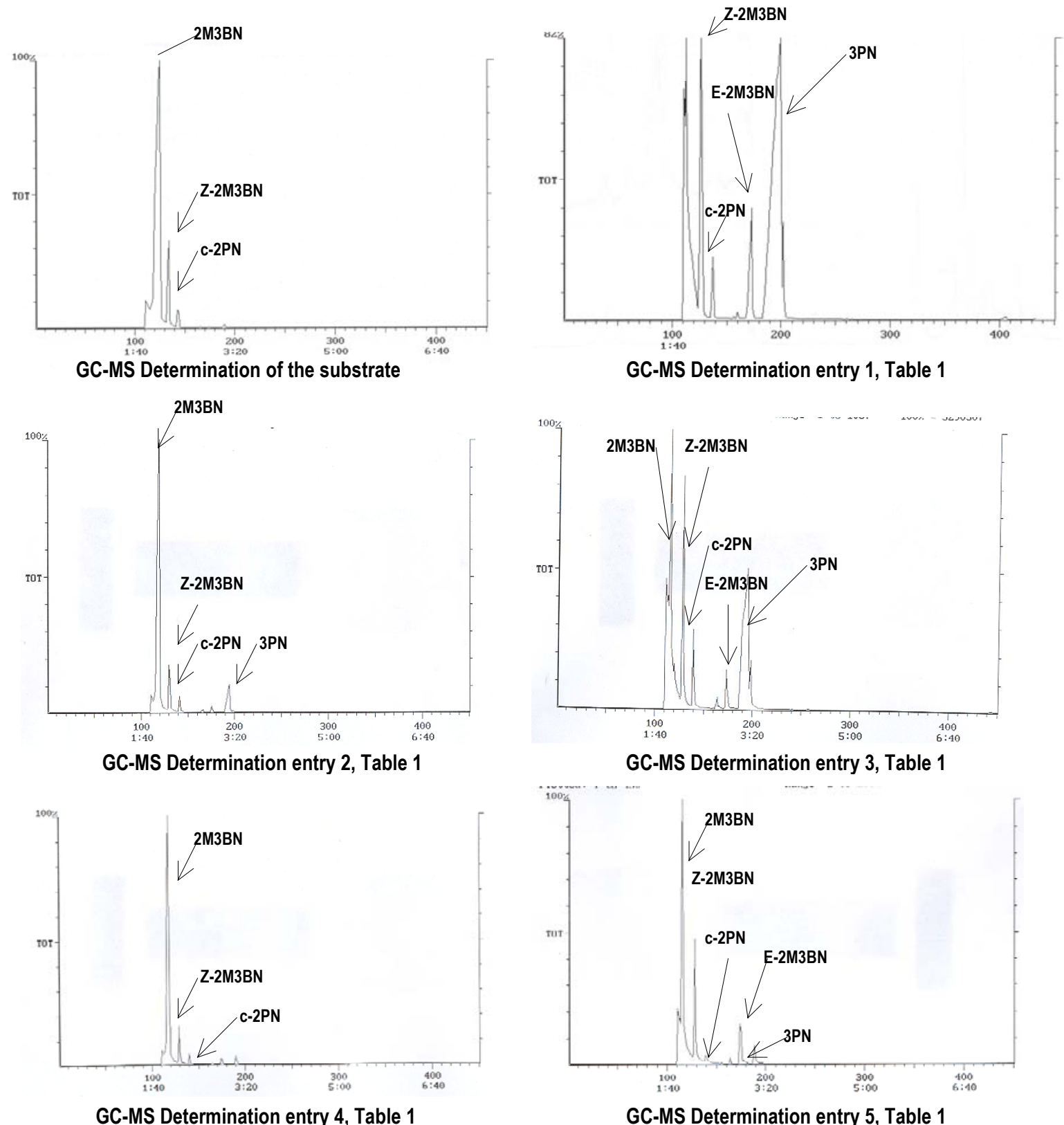

GC-MS Determination entry 4, Table 1

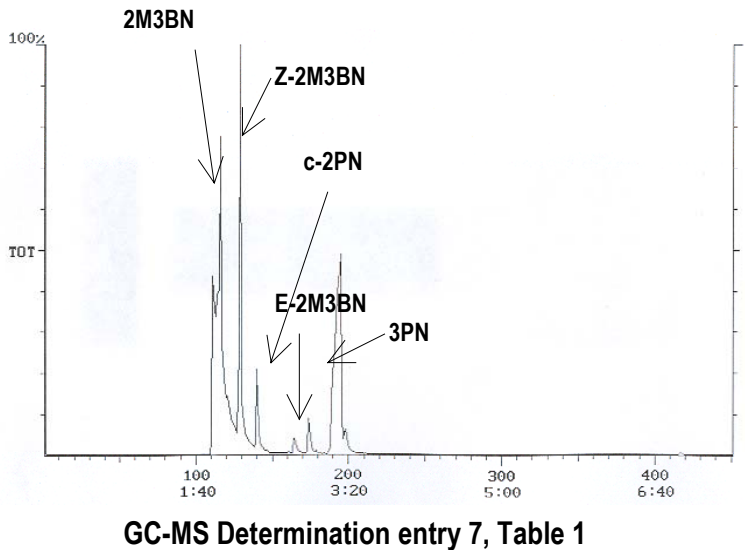




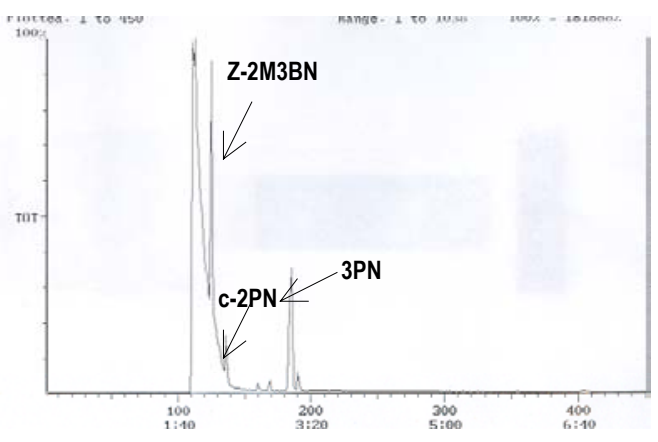

GC-MS Determination entry 1, Table 2

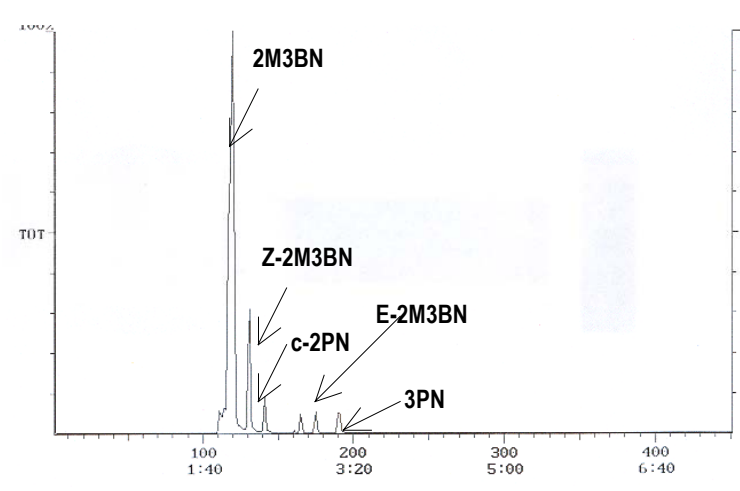

GC-MS Determination entry 2, Table 2

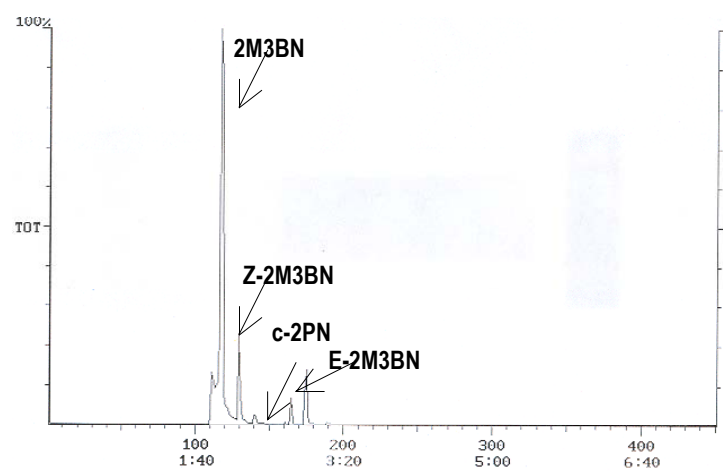

GC-MS Determination entry 4, Table 2

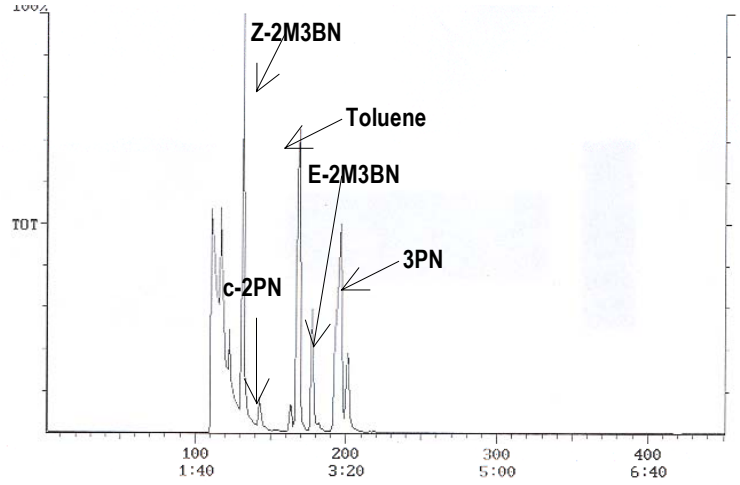

GC-MS Determination entry 3, Table 2

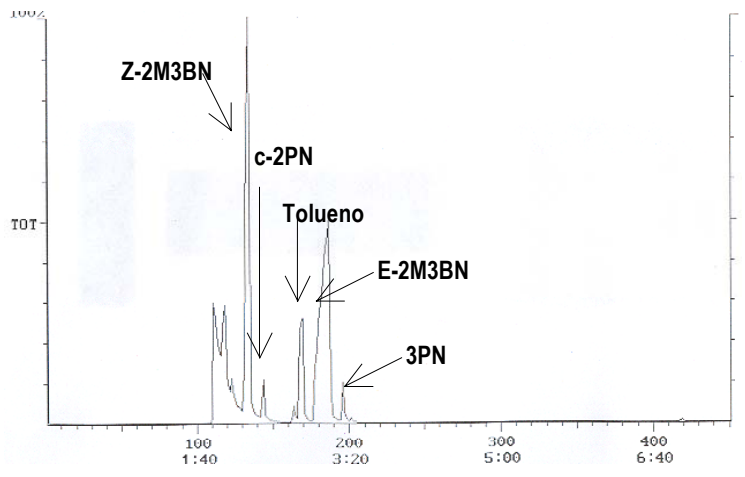

GC-MS Determination entry 5, Table 2

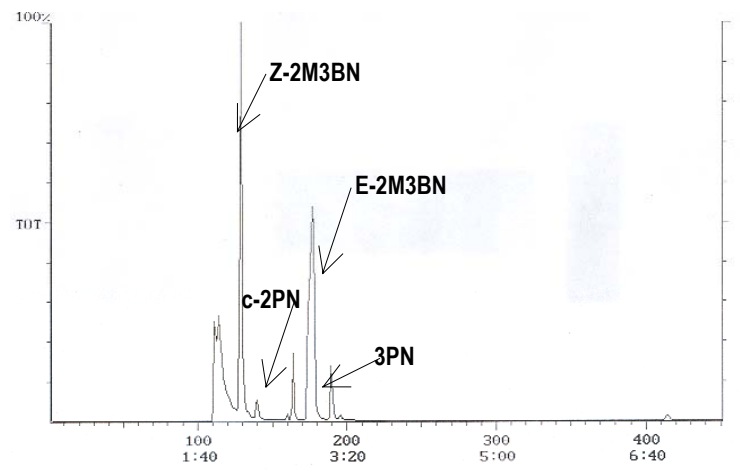

GC-MS Determination entry 6, Table 2 

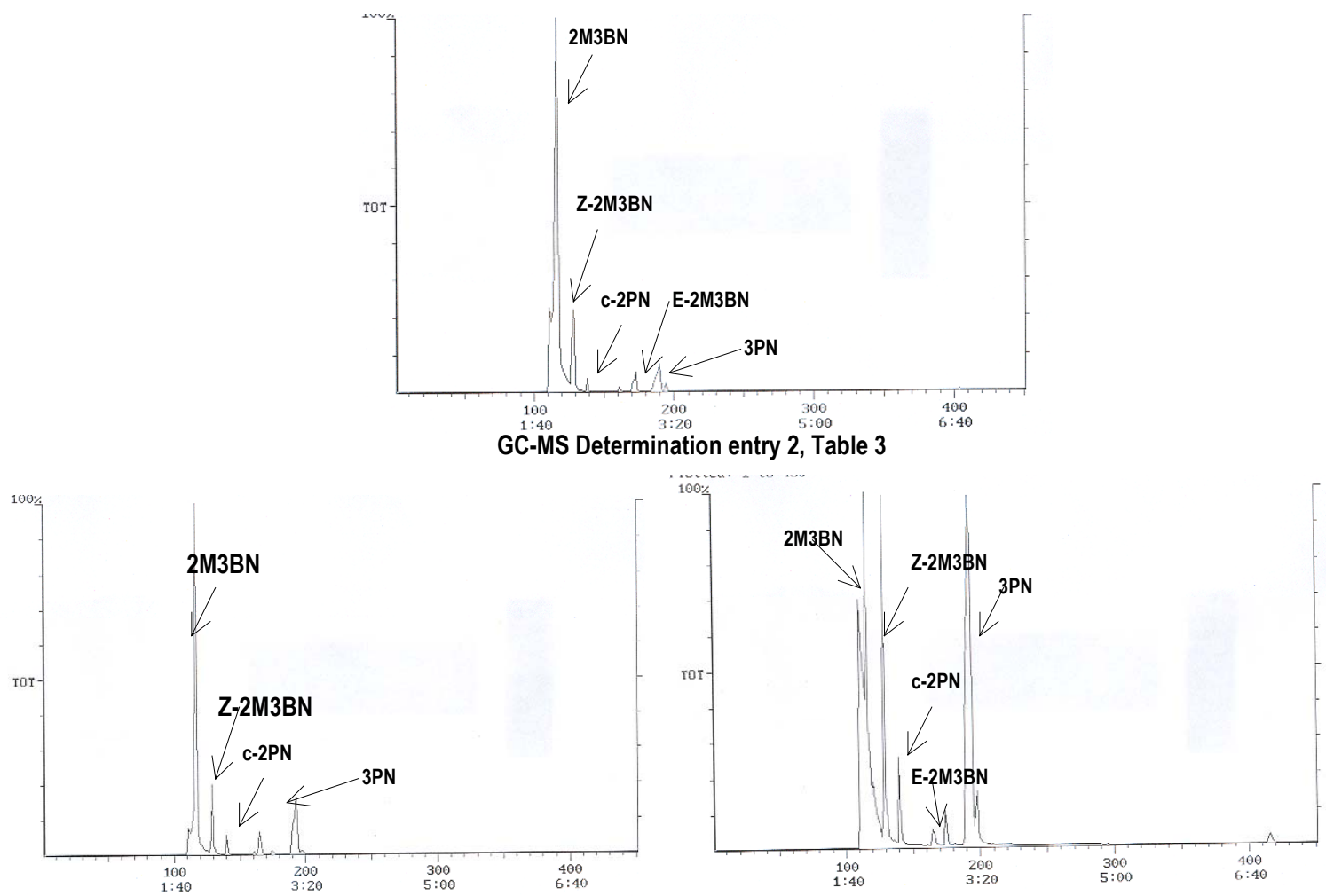

GC-MS Determination entry 3, Table 3

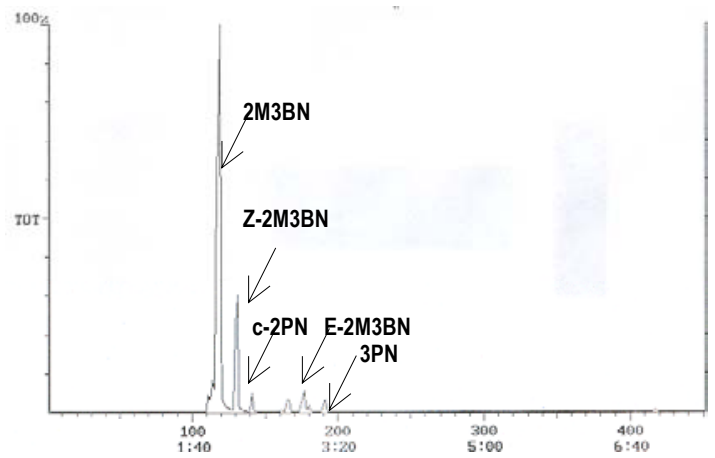

GC-MS Determination entry 4, Table 3

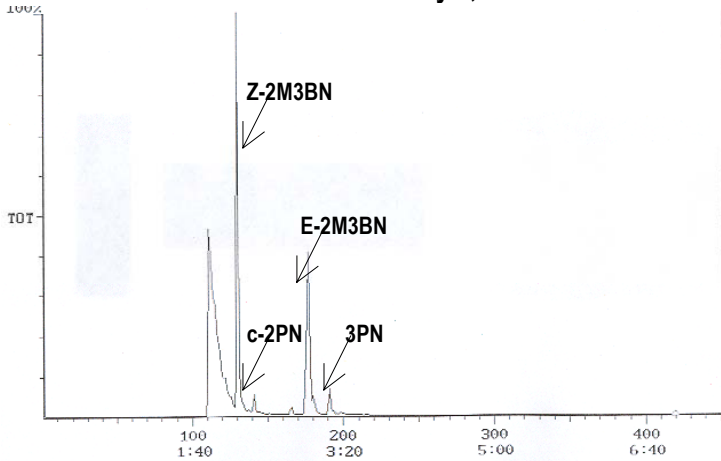

GC-MS Determination entry 5, Table 3

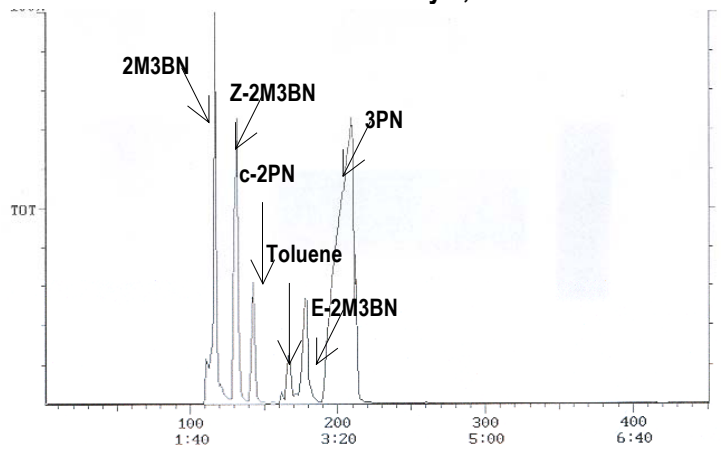

GC-MS Determination entry 7, Table 3

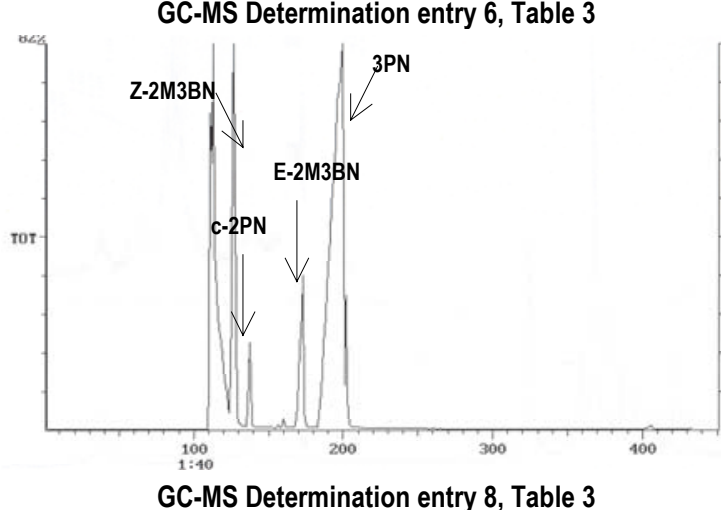




\section{General Experimental Procedures}

All manipulations were carried out using standard Schlenk and glove box techniques under Argon (Praxair 99.998). THF and hexane (J. T. Baker) were dried and distilled from dark purple and blue solutions of sodium/benzophenone ketyl, respectively. Toluene (J. T. Baker) was dried and distilled from sodium. Deuterated solvents were purchased from Cambridge Isotope Laboratories and stored over $3 \AA$ molecular sieves in an MBraun glove box $\left(<1 \mathrm{ppm} \mathrm{H}_{2} \mathrm{O}\right.$ and $\left.\mathrm{O}_{2}\right)$. [Ni(COD) $)_{2}$ was purchased from Strem and was purified by dissolving in THF, filtration through Celite, and vacuum drying to yield yellow crystalline $\left[\mathrm{Ni}(\mathrm{COD})_{2}\right]$, which was further dried for $3 \mathrm{~h}$ in vacuo. $\mathrm{BEt}_{3}$, tBuppf, dipf, and dppf-N ligands were purchased from Aldrich and were used as received. 2M3BN (86.5 \% by GC-MS) was purchased from TCI America, purged with nitrogen, and stored in the glove box. $\mathrm{ZnCl}_{2}$ was purchased from J. T. Baker and dried in vacuo. ${ }^{1} \mathrm{H},{ }^{13} \mathrm{C}\left\{{ }^{1} \mathrm{H}\right\}$, and ${ }^{31} \mathrm{P}\left\{{ }^{1} \mathrm{H}\right\} \mathrm{NMR}$ spectra were recorded at room temperature on a $300 \mathrm{MHz}$ Varian Unity spectrometer in THF- $d_{8}$, toluene- $d_{8}$ or $\mathrm{CD}_{2} \mathrm{Cl}_{2}$. ${ }^{1} \mathrm{H}$ chemical shifts $(\delta, \mathrm{ppm})$ are reported relative to the residual proton resonances in the deuterated solvent. ${ }^{13} \mathrm{C}\left\{{ }^{1} \mathrm{H}\right\}$ chemical shifts $(\delta)$ are reported relative to resonance of the deuterated solvent. All ${ }^{31} \mathrm{P}\left\{{ }^{1} \mathrm{H}\right\}$ NMR spectra were recorded relative to external $85 \% \mathrm{H}_{3} \mathrm{PO}_{4}$. Variable temperature ${ }^{31} \mathrm{P}\left\{{ }^{1} \mathrm{H}\right\}$ NMR spectra were recorded on a $400 \mathrm{MHz}$ Varian Unity spectrometer, for compound 1 the depicted spectra is for the corresponding reaction mixtures. All NMR spectra and catalytic reactions were carried out using thin wall $(0.38 \mathrm{~cm})$ WILMAD NMR tubes with J. Young valves. A Bruker APEX CCD diffractometer with monochromatized Mo K $\alpha$ radiation $(\lambda=0.71073 \AA)$ was used for the X-ray structure determinations. A crystal of 1 was mounted under Paratone 8277 on a glass fiber and immediately placed under a cold stream of nitrogen. Mass determinations (FAB + ) were recorded on a JEOL SX-102A using nitrobenzilic alcohol matrix and GC-MS determinations were recorded on a Varian Saturn 3, on a 30m DB-5MS capillary column.

Preparation of complex 1: A solution of tBuppf $(0.0725 \mathrm{mmol})$ in $2 \mathrm{~mL}$ of toluene was dropwise added to a stirred solution of $\left[\mathrm{Ni}(\mathrm{COD})_{2}\right](20 \mathrm{mg}, 0.0725 \mathrm{mmol})$ in $3 \mathrm{~mL}$ of toluene, giving a green-brown solution of [Ni(COD)(tBuppf)]. After stirring for $15 \mathrm{~min}$, a solution of $7 \mu \mathrm{L}$ of $2 \mathrm{M} 3 \mathrm{BN}$ $(0.0725 \mathrm{mmol})$ and $\mathrm{ZnCl}_{2}(0.0725 \mathrm{mmol})$ in $1 \mathrm{~mL}$ of toluene was added. After $30 \mathrm{~min}$ of stirring, an orange solution was obtained for $\mathbf{1}$. The solvent was then removed in vacuo and the residue was dried under vacuum for $3 \mathrm{~h}$, producing $\mathbf{1}$ as an orange solid (51.3 mg, 89\%), For 1, Ni-tBuppf-ZnCl $\mathbf{Z}_{\mathbf{2}}{ }^{1} \mathrm{H}$ NMR for (299.7 MHz, toluene- $\left.d_{8}\right)$ : $\delta 7.8$ (b, 2H, H arom), 6.92 (b, 8H, Harom), 5.38 (s, br, 1H, CH central), 4.29(b, 2H, Cp), 3.80 (b, 6H, Cp), 3.19 (s, br, 1H, CHMe), 2.0(s, br, 2H, CH2), 1.43 (s, Me, 
tBu, 9H), 1.39 (s, Me, tBu, 9H) and $1.22\left(\mathrm{~s}, \mathrm{br}, 3 \mathrm{H}, \mathrm{CH}_{3}\right) .{ }^{13} \mathrm{C}\left\{{ }^{1} \mathrm{H}\right\} \mathrm{NMR}\left(75.4 \mathrm{MHz}, \mathrm{CD}_{2} \mathrm{Cl}_{2}\right): \delta 151$ ppm (CN), 140-127 (C, arom), 116.7 (CH central), 91.1 (CHMe), 77.0 (b, $\left.\mathrm{C}_{\mathrm{ipso}}, \mathrm{Cp}\right), 76.4$ (b, $\left.\mathrm{C}_{\mathrm{ipso}} \mathrm{Cp}\right)$, 74.2-72.5(CH, Cp), $61.6\left(\mathrm{CH}_{2}\right), 35.2\left(\mathrm{~d},{ }^{2} \mathrm{~J}_{\mathrm{C}-\mathrm{P}}=12 \mathrm{~Hz}, \mathrm{C}\left(\mathrm{CH}_{3}\right)_{3}\right), 29.7\left(\mathrm{~b}, \mathrm{C}\left(\mathrm{CH}_{3}\right)_{3}\right)$ and $18.8\left(\mathrm{CH}_{3}\right)$. ${ }^{31} \mathrm{P}\left\{{ }^{1} \mathrm{H}\right\}\left(161.9 \mathrm{MHz}, \mathrm{CD}_{2} \mathrm{Cl}_{2}, 25^{\circ} \mathrm{C}\right): \delta 21.1$ (s, br) and $14.8(\mathrm{~s}, \mathrm{br}) . \mathrm{FAB}+: 628\left(\mathrm{M}^{+}-\mathrm{CN}-\mathrm{ZnCl}_{2}\right)$.

Catalytic isomerization of $2 \mathrm{M3BN}$ in the absence of LA. A solution of $2 \mathrm{M} 3 \mathrm{BN}(0.4 \mathrm{~mL}, 4.00$ $\mathrm{mmol}$ ) and $0.036 \mathrm{mmol}$ of the corresponding diphosphine were added to the yellow crystalline $\left[\mathrm{Ni}(\mathrm{COD})_{2}\right](10 \mathrm{mg}, 0.036 \mathrm{mmol})$, producing orange solutions. The mixture was transferred to an NMR tube with a J. Young valve, and the tube was heated to $100^{\circ} \mathrm{C}$ in an oil bath. After cooling to room temperature, a sample of the reaction mixture was taken and dissolved in THF inside the glove box and analyzed by GC-MS. A second sample was dissolved in toluene- $d_{8}$ and analyzed by ${ }^{1} \mathrm{H}$ NMR spectroscopy, showing identical resonances to those of a trans-3PN standard, as the major product.

Catalytic isomerization of $2 \mathrm{MBBN}$ in the presence of LA. The procedure was similar to that described above, but adding to the solutions $0.036 \mathrm{mmol}$ of $\mathrm{ZnCl}_{2}$ or $\mathrm{BEt}_{3}$. The mixture was transferred to an NMR tube with a J. Young valve, and the reaction tube was heated and analyzed as describe above.

The samples from catalytic experiments were analyzed by GC-MS on a 30m DB-5MS capillary column, ID $0.32 \mathrm{~mm}$, film 0.25 microns, $40 \mathrm{~mL} / \mathrm{min}$, using an isothermal $\mathrm{GC}$ method at $35^{\circ} \mathrm{C}$ during 8 minutes, followed by heating at $11.8^{\circ} \mathrm{C} / \mathrm{min}$ during 6.35 minutes, to reach $110^{\circ} \mathrm{C}$, being stable at that temperature for 3 more minutes. All the nitriles present in the samples are detected during the isothermal part of the method. 

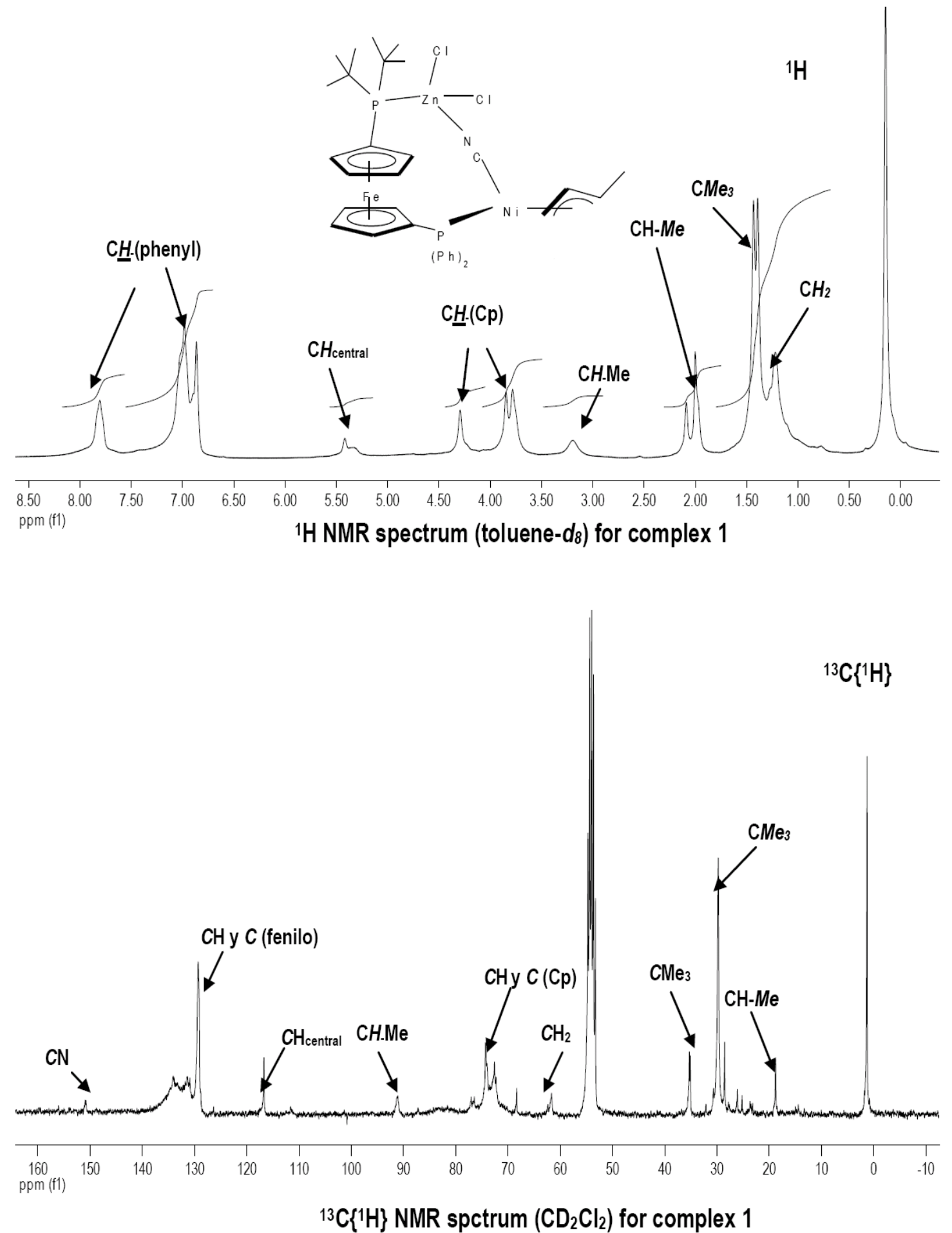